\title{
GOODYERA FUSCA (ORCHIDACEAE): A NEW RECORD FOR KASHMIR HIMALAYA, INDIA
}

\author{
Anzar A. Khuroo ${ }^{1,3}$, Gowhar A. Shapoo ${ }^{2}$, Shugufta Rasheed ${ }^{1}$, Zahoor A. Kaloo ${ }^{2}$ \\ \& SHAH RAFIQ ${ }^{2}$ \\ ${ }^{1}$ Centre for Biodiversity \& Taxonomy, Department of Botany, University of Kashmir, Srinagar- \\ 190 006, J \& K, India \\ ${ }^{2}$ Plant Tissue Culture Research Laboratory, Department of Botany, University of Kashmir, Srinagar- \\ 190006, J \& K, India \\ ${ }^{3}$ Corresponding author e-mail: anzarak@gmail.com
}

\begin{abstract}
Goodyera fusca, a rare orchid species is reported for the first time from the Kashmir Himalaya, India. A brief description and photographs of diagnostic features are provided. Comparative characters are also provided to distinguish G. fusca from Goodyera repens, already reported from Kashmir Himalaya. This newly reported terrestrial orchid species occurs in alpine habitats of this Himalayan region.
\end{abstract}

KeY words: alpine habitats, flora, Himalayas, new plant record

Introduction. Orchidaceae is the second largest family of flowering plants with 870 genera and $c a$. 25,000 species, distributed worldwide (Swarts \& Dixon 2009, Rao et al. 2012). Orchids are widely distributed in tropical, subtropical and temperate regions in all continents except Antarctica, but reach their maximum diversity in the humid tropical regions. The family constitutes $9 \%$ of the total Indian flora and is represented by 177 genera with $c a$. 1,195 species (Misra 2007, Singh et al. 2001). In India, the Himalayas represent one of the global biodiversity hotspots (Mittermeier et al. 2005), and are well-known to harbor a rich diversity of orchids (Vij \& Pathak 2010, Jalal \& Jayanthi 2015).

In the northwestern extreme of the Indian Himalayas, the Kashmir Himalaya constitutes a biodiversity-rich region (Dar \& Khuroo 2013). From this region, 44 orchid species have been recorded (Duthie 1906, Naqshi et al. 1989, Akhter et al. 2011), including one species of the genus Goodyera, i.e. G. repens (L.) R.Br. (Kant \& Chander 2004, Akhter et al. 2011). During recent botanical surveys in the Thajwas Wildlife Sanctuary, Sonamarg, Kashmir, the authors collected a hitherto unrecorded plant species from the region. After a detailed study of diagnostic characteristics of the fresh plant material and perusal of taxonomic literature, the species was identified as Goodyera fusca (Lindl.) Hook.f. which turned out to be a new record for the flora of Kashmir Himalaya. In order to validate this new record, the present paper provides a detailed taxonomic description, microphotographs of diagnostic characters (Figure 1) delimiting characters from its con-generic species occurring in this region (Table 1), which will facilitate its field identification.

Materials and Methods. Standard taxonomic methods have been used for collection, drying, and further processing of the herbarium specimens (Bridson \& Forman 1998) deposited in the Kashmir University Herbarium (KASH) with a proper voucher specimen number. The fresh plant specimens have been identified using relevant taxonomic literature (Hooker 1897, Stewart 1972, Duthie 1906, King \& Pantling 1979, Deva \& Nathani 1986). The photographs of the diagnostic characters were taken with Handheld Portable microscope (Make: DINO Lite AM4515ZT4).

TAXONOMIC TREATMENT

Goodyera fusca (Lindl). Hook. f. Fl. Brit. India 6: 112, 1890.

Bas.: Hetaeria fusca Lindl. Syn.: Cystorchis fusca 

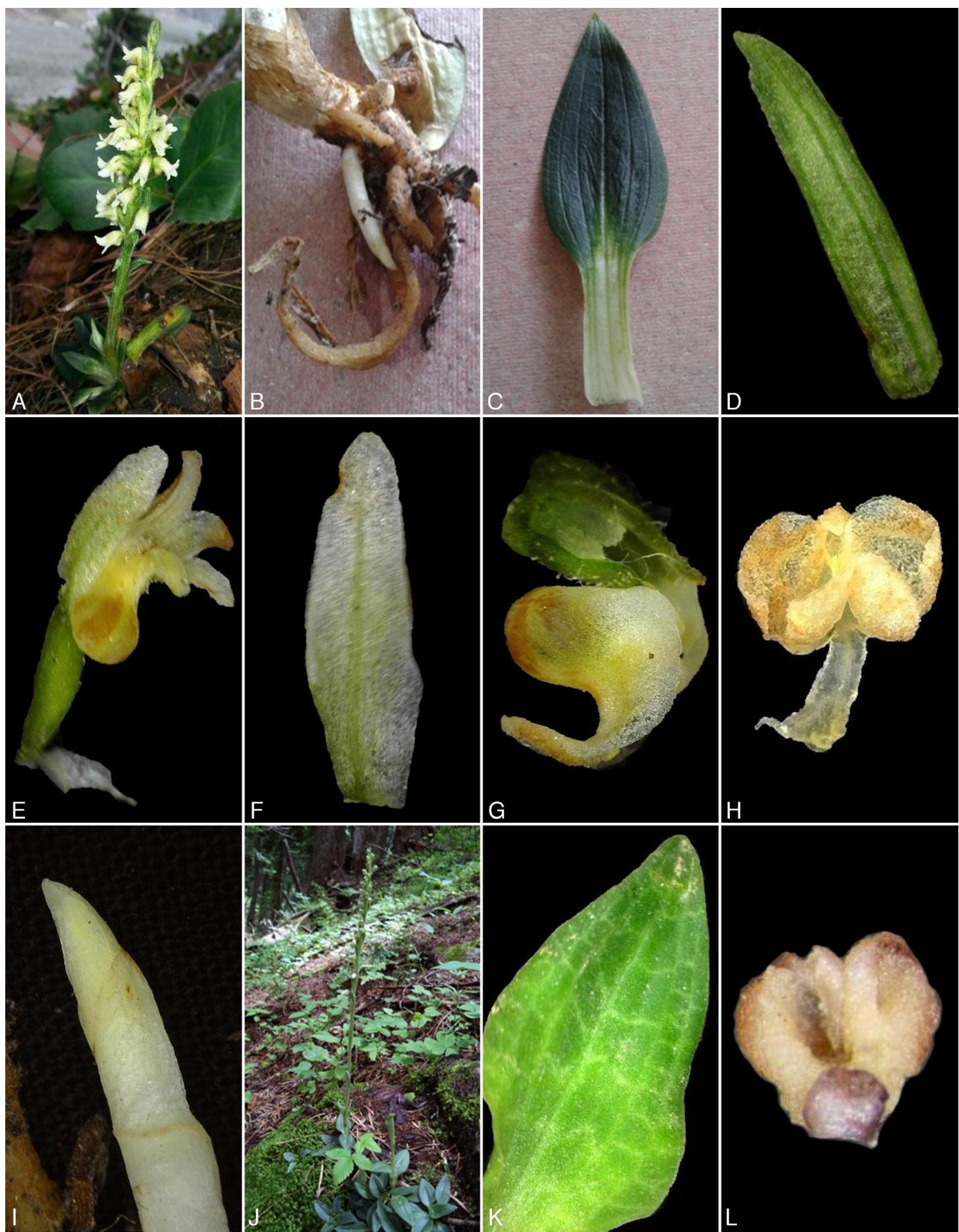

Figure 1. Figure 1. Goodyera fusca (Lindl.) Hook.f. A. Habit. B. Rootstock. C. Leaf. D. Bract. E. Flower. F. Sepal. G. Labellum. H. Pollinia. I. Tuber. J. G. repens (L.) R.Br. K. Surface of leaf of G. repens. L. Pollinia of G. repens. (Photo credits: Anzar A. Khuroo, Gowhar A. Shapoo, Shugufta Rasheed, and Shah Rafiq). 
TABLE 1. Comparison of diagnostic characters between G. repens and G. fusca occurring in the Jammu and Kashmir, India.

\begin{tabular}{|l|l|l}
\hline Diagnostic characters & \multicolumn{1}{|c|}{ G. repens } & \multicolumn{1}{c}{ G. fusca } \\
\hline Leaf & Whitish green, marbled & Thick, fleshy, 5-nerved \\
\hline Petiole & Sheathing in lower half & Sheathing at the base \\
\hline Bracts & Linear-lanceolate & Ovate-oblong \\
\hline Petals & $\begin{array}{l}\text { Lanceolate, adhering on the inner margins to the } \\
\text { dorsal sepal }\end{array}$ & Sigmoid, linear-oblong, sub-acute \\
\hline Lip/Labellum & Sac of the lip papillose without any ridges inside & Sac of the lip glabrous with two ridges inside \\
\hline
\end{tabular}

(Lindl.) Benth. \& Hook. f.; Epipactis fusca (Lindl.)

A.A.Eaton, Orchiodes fusca (Lindl.) Kuntze.

Terrestrial leafy herb, height $16 \mathrm{~cm}$. Stem glabrous, $8 \mathrm{~cm}$ long. Leaves clustered near the base, thick ovate, $4 \mathrm{~cm}$ long, 5-nerved, margins revolute, petiole $6 \mathrm{~mm}$ broad. Bracts leaf-like, oblong, $6 \mathrm{~mm}$ long. Inflorescence a many-flowered raceme, longer than the stem, $5.5 \mathrm{~cm}$ long. Flowers $5 \mathrm{~mm}$ long, pubescent, white flushed green. Sepals sub-equal, oblong, subacute, $4.4 \mathrm{~mm}$. Petals linear, $5.15 \mathrm{~mm}$ long, oblong sigmoid, subacute. Labellum (lip) as long as sepals, deeply sub-globose at the base, sac of the lip with two ridges, glabrous inside, base conspicuously projecting beyond the base of the sepals. Column $1.5 \mathrm{~mm}$ long. Pollinia 2, broadly ovoid.

SPECIMEN EXAMINED. India. Kashmir: District Ganderbal, Thajwas Wildlife Sanctuary, Sonamarg, 23-08-2017, Khuroo and Shapoo 0157 (KASH).

HaBitat: Grows on open mountain slopes, in rock crevices with a dense layer of decomposed humus in the alpine zone at an elevation of $3700 \mathrm{~m}$.

Phenology: Flowering was recorded in AugustSeptember.

Global Distribution: China, Myanmar, Bhutan, Nepal, India (Arunachal Pradesh to Himachal Pradesh); and now extended further westwards to Kashmir Himalaya.

AcKNOWLEDGMENTS. The authors are thankful to the Head of Department of Botany, University of Kashmir, Srinagar for providing the necessary facilities. The supporting staff members at the Centre for Biodiversity and Taxonomy, University of Kashmir are also acknowledged for their kind help during the course of the present study. We acknowledge help by Dr. Pankaj Kumar, IUCN-SSC Orchid Specialist Group Asia, who confirmed the scientific identification. The useful comments made by the esteemed reviewers are also acknowledged.

\section{LiTERATURE CITED}

Akhtar, C., Khuroo, A. A., Dar, G. H., Khan, Z. S. \& Malik, A. H. (2011). An updated checklist of orchids in the Indian Himalayan State of Jammu and Kashmir. Pleione, 5(1), 1-9.

Bridson, D. \& Forman, L. (1998). The Herbarium Handbook. 3rd ed. Kew: Royal Botanic Gardens.

Dar, G. H. \& Khuroo, A. A. (2013). Floristic diversity in the Kashmir Himalaya: Progress, Problems and Prospectus. Sains Malaysiana, 42, 1377-1386.

Deva, S. \& Naithani, H. B. (1986). Orchids of the northwestern Himalaya. Dehradun, India: Bishen Singh Mahendra Pal Singh.

Duthie, J. F. (1906). Orchids of the North Western Himalaya. Calcutta, India: Bengal Secretariat Press.

Flora of China Editorial Committee. (2009). Orchidaceae. In: C. Y. Wu, P. H. Raven \& D. Y. Hong (Eds.), Flora of China (25, 1-570). Beijing \& St. Louis: Science Press $\&$ Missouri Botanical Garden Press.

Hooker, J. D. (1897). Flora of British India. Dehradun, India: Bishen Singh Mahendra Pal Singh.

Jalal, J. S. \& Jayanthi, J. (2015). An annotated checklist of the orchids of western Himalaya, India. Lankesteriana, 15(1), 7-50.

King, S. G. \& Pantling, R. (1979). Orchids of Sikkim Himalaya. Vol. 8. Dehradun, India: Bishen Singh Mahendra Pal Singh.

Mittermeier, R. A., Gil, R. P., Hoffman, M., Pilgrim, J., Brooks, T., Mittermeier, C. G. \& Fonseca, G. A. B. (2005). Hotspots revisited: Earth's bio-logically richest and endangered terrestrial eco-regions. Boston: University of Chicago Press.

Misra, S. (2007). Orchids of India. A glimpse. Dehradun, India: Bishen Singh Mahendra Pal Singh.

Naqshi, A. R., Malla, M. Y. \& Dar, G. H. (1989). Plants of Ladakh, Nubra. Journal of Economic \& Taxonomic Botany, 13(3), 539-560.

Rao, B. R. P., Prasad, K., Bheemalingappa, M., Naik, M. C., Ganeshaiah, K. N. \& Sanjappa, M. (2012). Conservation status of Dendrobium tenuicaule Hook. f. (Orchidaceae), a Middle Andaman Island endemic, India. Journal of Threatened Taxa, 4(15), 3410-3414. 
Shashi, K. \& Harish, C. (2004). Orchids of Jammu Province (Jammu and Kashmir, India). In: A. N. Kamili \& A. R. Yousuf (Eds.), Bioresources: Concerns and Conservation. Srinagar, India: Centre of Research for Development, University of Kashmir.

Singh, K. P., Phukan, S. \& Bujarbarua, P. (2001). Orchidaceae. In: N. P. Singh \& D. K. Singh (Eds.), Floristic Diversity and Conservation Strategies in India (4, 1735-1846.). Kolkata: Botanical Survey of India.

Stewart, R. (1972). An annotated catalogue of vascular plants of West Pakistan and Kashmir. Karachi: Fakhri Printing Press.

Swarts, N. D. \& Dixon, K. W. (2009). Terrestrial orchid conservation in the age of extinction. Annals of Botany, 104, 543-556.

Vij, S. P. \& Pathak, P. (2010). Orchids: Application of tissue culture techniques for sustainable development. $I n$ : L. M. Tewari, Y. P. S. Pangtey \& G. Tewari (Eds.), Biodiversity potentials of the Himalaya. Nainital, India: Gyanodaya Prakashan. 